\title{
Subsidiarity and the European Convention on Human Rights
}

\author{
Alastair Mowbray, Professor of Public Law, University of Nottingham
}

\begin{abstract}
Theoretical views on the concept of subsidiarity are examined followed by an analysis of the origins of the principle of subsidiarity within the ECHR. The Court's utilisation of the principle, as disclosed by the jurisprudence, is studied across three time periods encompassing the original part-time Court, the first decade of the full-time Court and the post-Interlaken era. This is supplemented by a consideration of some quantitative data, derived from the Court's HUDOC database, on the usage of subsidiarity in the case reports of Court judgments. Particular attention is given to Grand Chamber judgments since 2010. Overall conclusions are then drawn on, inter alia, whether the Court's use of the principle has altered over time, whether the principle is simply a device to limit the authority of the Court, who can benefit from the application of the principle and what links may be made between the theoretical writings and the actual judgments delivered at Strasbourg.
\end{abstract}

As is well known the principle of subsidiarity has gained an increasingly high profile in the ongoing reform process of the European Convention on Human Rights ${ }^{1}$ (hereinafter "the Convention" or "the ECHR") during recent years culminating in Protocol $15^{2}$ adding a reference to the principle at the end of the Preamble of the Convention. ${ }^{3}$ Indeed, a serving judge at the European Court of Human Rights (hereinafter "the Court") has extra-judicially described the current era as the "Age of Subsidiarity". ${ }^{4}$ Therefore, now is an opportune time to stand back and examine the conceptual origins of the principle and its emergence within the ECHR system. How has the Court been using the principle and has that changed over the decades of the Court's evolution from a part-time adjudicatory body with a limited jurisdiction to the main institution responsible for applying and interpreting the Convention at the international level ${ }^{5}$

\section{The conceptual nature and history of subsidiarity}

Carozza has provided a working definition of subsidiarity in the following terms, "subsidiarity is the principle that each social and political group should help smaller or more local ones accomplish their respective ends without, however, arrogating those

\footnotetext{
${ }^{1}$ Convention for the Protection of Human Rights and Fundamental Freedoms, CETS No. 005, Rome $4^{\text {th }}$ November 1950.

${ }^{2}$ Protocol No. 15 amending the Convention for the Protection of Human Rights and Fundamental Freedoms, CETS No. 213, Strasbourg $24^{\text {th }}$ June 2013.

${ }^{3}$ See A. Mowbray, “European Court of Human Rights: May 2013-April 2014, 20(4) Eur. Pub. L. 579 (2014).

${ }^{4}$ R. Spano, "Universality or Diversity of Human Rights? Strasbourg in the Age of Subsidiarity", 14(3) H.R.L.R. 487 (2014).

${ }^{5}$ On the historical development of the Convention see, E. Bates, The Evolution of the ECHR, (Oxford: OUP, 2010).
} 
tasks to itself." ${ }^{6} \mathrm{He}$ explained that its origins went back to the time of classical Greece and subsequently it was revived during the medieval period by Thomas Aquinas. In the seventeenth century Johannes Althusius applied subsidiarity as an aspect of his theoretical views regarding the role of a secular federal state. These were later developed by political theorists including Montesquieu, Locke, Tocqueville and Proudhon. Towards the end of the nineteenth century Roman Catholic social theorists embraced the principle as a means of seeking to promote a socio-economic model that stood between the extremes of laissez-faire capitalism and Marxist proletarian rule. In 1891 Pope Leo XIII issued his social encyclical Rerum Novarum in which he advocated limited state intervention in economic relations to protect the basic interests of workers. "Whenever the general interest or any particular class suffers, or is threatened with harm, which can in no other way be met or prevented, the public authority must step in to deal with it...the principle being that the law must not undertake more, nor proceed further, than is required for the remedy of the evil or the removal of the mischief." ${ }^{7}$ On the fortieth anniversary of the above encyclical Pope Pius XI issued his own encyclical Rerum Novarum (1931) with a greater emphasis on the principle of subsidiarity as a justification for limited state intervention.

...Just as it is gravely wrong to take from individuals what they can accomplish by their own initiative and industry and give it to the community, so also it is an injustice and at the same time a grave evil and disturbance of right order to assign to a greater and higher association what lesser and subordinate organizations can do. ...The supreme authority of the State ought, therefore, to let subordinate groups handle matters and concerns of lesser importance, which would otherwise dissipate its efforts greatly. ...Therefore, those in power should be sure that the more perfectly a graduated order is kept among the various associations, in observance of the principle of "subsidiary function", the stronger social authority and effectiveness will be [and] the happier and more prosperous the condition of the State." ${ }^{8}$

Carozza then notes how the principle was incorporated into the constitutional order of post-Second World War "West" Germany to distribute legal powers away from an overbearing central government system. Two decades later Ralph Dahrendorf, a German member of the European Commission, publicly argued for the application of the principle to reduce the bureaucratic powers of the European Economic Community (EEC) over agricultural policy. He advocated the Community should, "move away from the dogma of harmonization towards the principle of subsidiarity. ${ }^{\prime \prime}$ During the next twenty years the principle became increasingly prominent in the official discourse of the EEC and was formally incorporated in the text of the Treaty on European Union ${ }^{10}$. Article 2 stating that, "[t]he objectives of the Union shall be achieved as provided in this Treaty...while

\footnotetext{
${ }^{6}$ P.G. Carozza, "Subsidiarity as a Structural Principle of International Human Rights Law", 97 Am. J. Int'l L. 38 (2003).

${ }^{7}$ lbid. at p. 41.

${ }^{8}$ Ibid. at p. 42.

${ }^{9}$ Ibid at p. 50.

${ }^{10}$ Maastricht, 1991.
} 
respecting the principle of subsidiarity." That obligation was elaborated in Article 5 which provided, "[i]n areas which do not fall within its exclusive competence, the Community shall take action, in accordance with the principle of subsidiarity, only if and insofar as the objectives of the proposed action cannot be sufficiently achieved by the Member States and can therefore, by reason of the scale or effects of the proposed action, be better achieved by the Community."

Subsidiarity was incorporated into the Maastricht Treaty as a result of political forces according to Carozza in order to assuage concerns that European Community/Union institutions were becoming too centralised and powerful.

Follesdal, a Professor of Philosophy based in a human rights centre, has identified five different models of the principle of subsidiarity; which he defines as regulating "how to allocate or use authority within a political or legal order, typically in those orders that disperse authority between a centre and various member units." ${ }^{11}$ First, the "liberty, Althusius" model based upon the ideas of the "father of federalism", whom we have noted above. In this conception of subsidiarity, "[t]he role of the state is to co-ordinate and secure symbiosis among associations-on a consensual basis." ${ }^{12}$ The second model, "liberty, confederalists", is derived from American confederalists and their supporters, such as Montesquieu. "This view starts from the plausible assumptions that individuals should not be subjected to the arbitrary will of others in matters where no others are harmed, and that smaller groups are more likely to share preferences." ${ }^{13}$ The third conceptual view is that of "efficiency, economic federalism" and "holds that powers and burdens of public goods should be placed with the populations that benefit from them."14 Follesdal considered that this model has wider aims that the Althusian theory as it seeks to elaborate standards for the distribution of powers. The former associates this model with advocates of sceptical views towards the accumulation of authority by the European Union. The fourth model is that of "justice, Catholic personalism" and embodies the Papal encyclicals discussed previously. The final model is the "liberal contractualist", derived from theorists of this school, including John Rawls. At its heart, "[c]entral authorities should seek to support member units' democratic and informed decisionmaking, and they should also respect member units' immunity against influence- as long as the decisions respect the best interests of its members and avoid local domination. ${ }^{\prime 15}$ Ultimately, Follesdal concludes that:

"The" principle of subsidiarity cannot on its own provide legitimacy or contribute to a defensible allocation of authority between national and international institutions, e.g., regarding human rights law. Appeals to subsidiarity are too vague, and require attention to more items- including the standing of states, whether centre action is prohibited or required, and who should decide such issues. The more

\footnotetext{
${ }^{11}$ A. Follesdal, "The Principle of Subsidiarity as a Constitutional Principle in International Law", Global Constitutionalism (2013) 2:1, 37.

${ }^{12}$ Ibid. at p. 42.

${ }^{13}$ Ibid. at p. 43.

${ }^{14}$ Ibid. at p. 45.

${ }^{15}$ Ibid. at p. 48.
} 
plausible versions of subsidiarity insist that ultimately, these questions are answered in light of which arrangements benefit individual person's interests better than the alternatives." 16

So, turning to the more specific features of the ECHR system, we will now consider some of the thoughts of academics and judges on the nature and roles of the principle of subsidiarity within this jurisdiction. von Staden, an international organizations academic, sees "an element of subsidiarity" being integrated into the "institutional design"17 of the Court via the requirement that applicants exhaust domestic remedies prior to being eligible to lodge an application at Strasbourg. ${ }^{18}$ "This requirement gives expression not only to the duty of domestic institutions to try to remedy alleged human rights violations, but also to their right to do so in line with their domestic arrangements for resolving such disputes. ${ }^{19}$ He also considers that the Court's margin of appreciation doctrine can be viewed as an instrument of "normative subsidiarity". The latter concept is elaborated as expressing "a preference for the lower level in order to protect values associated with governance at the lower level". ${ }^{20}$ Professor Kuijer has also identified Article 13 of the ECHR, right to an effective remedy, as another source of subsidiarity within the Convention. "Article 13 is the embodiment of the principle of subsidiarity, which is one of the underlying foundations of the Convention mechanism." ${ }^{21}$

Professor de Londras, whilst contributing to the debate about what should be the dominant function of the Court ${ }^{22}$, argues that the "subsidiary nature" of the Court supports her belief that it should focus on a "constitutionalist function"23, which she defines as involving, inter alia, the judicial clarification and development of human rights standards ${ }^{24}$. However, she also identifies another form of subsidiarity within the ECHR system:

When we speak of subsidiarity our tendency is to consider this as a relationship strictly between domestic courts and the European Court of Human Rights, but for the Court to be secure and the Convention to be effective it also requires a level of

\footnotetext{
${ }^{16}$ Ibid. at p.62.

${ }^{17}$ A. von Staden, "The Democratic Legitimacy of Judicial Review Beyond the State: Normative Subsidiarity and Judicial Standards of Review", I.CON 10 (2012), 1023 at p. 1036.

${ }^{18}$ Now found in Article 35(1) of the ECHR.

${ }^{19}$ Supra n. 17 at p. 1036.

${ }^{20}$ Ibid. at p. 1035.

${ }^{21}$ M. Kuijer, "The Right to a Fair Trial and the Council of Europe's Efforts to Ensure Effective Remedies on a Domestic Level for Excessively Lengthy Proceedings", 13(4) H.R.L.R. 779 at p. 785 (2013).

${ }^{22}$ See also S. Greer \& L. Wildhaber, "Revisiting the debate about "constitutionalising" the European Court of Human Rights" 12(4) H.R.L.R. 655 (2012).

${ }^{23}$ F. de Londras, "Dual Functionality and the Persistent Frailty of the European Court of Human Rights", (2013) E.H.R.L.R. 38 at p. 46.

${ }^{24}$ Ibid. at p. 40.
} 
political subsidiarity between the Council of Europe's political processes and the Court. This, as has already been argued, allows for systemic or endemic rights violations to be tackled as a political matter, particularly since the judgments of the Court already handed down in relation to those violations have not been executed fully or in a manner that in fact addresses the violations in question. ${ }^{25}$

From this fascinating perspective the principle of subsidiarity does not simply encompass a bilateral relationship between the Court and domestic authorities (judicial and, I would submit, legislative and executive too), but also multilateral relationships between the Court and the political organs of the Council of Europe (namely, the Committee of Ministers and the Parliamentary Assembly).

J-P Costa, the former President of the Court, has, like von Staden, identified the Convention's requirement for applicants to exhaust domestic remedies before applying to the Court as enshrining the subsidiarity principle. ${ }^{26}$ In his view this "key provision" meant that the principle of subsidiarity did not need to be "restated" in the Preamble of the Convention "except for symbolic or political reasons". ${ }^{27}$ His successor President Spielmann publicly observed that, "[t]he future imagined at Brighton is one where the centre of gravity of the Convention system can be lower than it is today, closer in time and space to all Europeans, and to all those under the protection of the Convention." ${ }^{28}$ We will be examining the Protocol reform process and its effects on the principle of subsidiarity in greater detail below. In his London lecture President Spielmann also praised the UK as "a model in terms of subsidiarity thanks to the Human Rights Act." 29

Judge Spano, responding to Lord Hoffmann's criticisms of the Court ${ }^{30}$, explained his view that in recent years the Court has been developing "a more robust and coherent concept of subsidiarity." ${ }^{31}$ Building upon cases such as the Grand Chamber's judgment in

\footnotetext{
${ }^{25}$ Ibid. at p. 44.

${ }^{26}$ J-P. Costa, "The Relationship between the European Court of Human Rights and the national courts", (2013) E.H.R.L.R. 264 at p. 267.
}

27 Ibid.

${ }^{28}$ D. Spielmann, "Whither the Margin of Appreciation?", UCL- Current Legal Problems lecture, London 20 Mar. 2014 at p.12.

${ }^{29}$ Ibid.

${ }^{30}$ Lord Hoffmann, "The Universality of Human Rights", Judicial Studies Board Annual Lecture, 19 Mar. 2009. For recent contributions to the extrajudicial debate between British and Strasbourg judges see: Sir Nicholas Bratza, "The Convention, the Common Law and the Strasbourg Court- Apocalypse Now?", Nottingham University, 12 March 2014 (www.nottingham.ac.uk/law/news/2014/march/sir-nicholas-bratza-speaks-at-theschool-of-law.aspx) and Lord Phillips of Worth Matravers, "European Human Rights-A Force for Good or a Threat to Democracy?", King's College London, 17 June 2014 (thanks to my colleague Professor Dirk Van Zyl Smit for alerting me to this lecture). Academic perspectives include: M. Amos, "The Dialogue Between UK Courts and the European Court of Human Rights", (2012) I.C.L.Q. 557 and E. Bates, "Analysing the Prisoner Voting Saga and the British Challenge to Strasbourg", 14(3) H.R.L.R. 503 (2014).

${ }^{31}$ Supra n. 4 at p. 491. 
Hatton $v U K^{32}$, he believes that, in respect of qualified rights under the $\mathrm{ECHR}^{33}$, the Court has paid particular attention to how the domestic authorities (especially parliaments) have sought to balance the conflicting interests when determining if a violation of the Convention has occurred. ${ }^{34}$ "With this qualitative, democracy-enhancing approach, the Court's reformulation or refinement of the principle of subsidiarity, and the margin of appreciation, introduces a clear procedural dimension that can be examined on the basis of objective factors informed by the defendant government in its pleadings. ${ }^{\prime \prime 5}$ This methodology should contribute, according to Judge Spano, to alleviating any concerns that the Court has been engaging in "human rights imperialism".

The above materials disclose the long history of the notion of subsidiarity as a construct, elaborated by both secular and religious figures, to govern the distribution of powers between different authorities. Given the centuries of gestation it is not surprising that different conceptual views of subsidiarity have been proclaimed by a variety of persons who have sought to utilise it across a diverse range of contexts, from delimiting the boundaries between state and church activities to allocating powers between national governments and regional supra-national organisations. Likewise within public debates about the ECHR system we have seen various academics and judges invoking the principle as an element in discussions on a broad canvass of issues from what should be the primary function of the Court to relations between national judges and their Strasbourg counter-parts. These papers have also provided us with valuable insights into the Convention origins of the principle. We are now going to deepen our understanding of this vital issue by examining the Court's jurisprudence.

\section{The Legal Origins of the Principle of Subsidiarity within the ECHR}

The text of the Convention, subject to the amendment of the Preamble to be introduced under Protocol 15, contains no mention of the term subsidiarity. Indeed, in his pioneering examination of the principle during the era of the original Court, Petzold (Deputy Registrar of that Court) noted that, "it was not even referred to in the discussions leading up to the drafting and adoption of the Convention." ${ }^{36}$ His explanation being that the drafters saw the ECHR as "a basic law" for an international organization (the Council of Europe) with intergovernmental aims, not including political integration. Therefore, we have to look to the Court's case-law to discover the Convention foundations of the principle.

The Grand Chamber has in several judgments expressly identified Articles 1 (obligation to respect human rights), 13 (right to an effective remedy) and 35(1)

\footnotetext{
32 Judgment of 8 July 2008.

${ }^{33}$ Notably Articles 8-11.

${ }^{34}$ More generally on this topic see, A. Mowbray, "A study of the Principle of Fair Balance in the Jurisprudence of the European Court of Human Rights", 10(2) H.R.L.R. 289 (2010).

${ }^{35}$ Supra n. 4 at p. 499.

${ }^{36}$ H. Petzold, "The Convention and the Principle of Subsidiarity" in R. St.J. Macdonald, F. Matscher \& H. Petzold, The European System for the Protection of Human Rights, (Dordrecht: Martinus Nijhoff, 1993) at p. 42. Furthermore, Bates supra n.5 does not list "subsidiarity" as a heading in his index.
} 
(admissibility criteria) as the Convention bases for the principle of subsidiarity. In Kudla $\checkmark$ Poland ${ }^{37}$ the Grand Chamber stated:

By virtue of Article 1 (which provides: "The High Contracting Parties shall secure to everyone within their jurisdiction the rights and freedoms defined in Section I of this Convention"), the primary responsibility for implementing and enforcing the guaranteed rights and freedoms is laid on the national authorities. The machinery of complaint to the Court is thus subsidiary to national systems safeguarding human rights. This subsidiary character is articulated in Articles 13 and $35 \S 1$ of the Convention.

The purpose of Article $35 \S 1$, which sets out the rule on exhaustion of domestic remedies, is to afford the Contracting States the opportunity of preventing or putting right the violations alleged against them before those allegations are submitted to the Court (see, as a recent authority, Selmouni v. France [GC], no. 25803/94, § 74, ECHR 1999-V). The rule in Article $35 \S 1$ is based on the assumption, reflected in Article 13 (with which it has a close affinity), that there is an effective domestic remedy available in respect of the alleged breach of an individual's Convention rights (ibid.). ${ }^{38}$

Subsequently in Cocchiarella $v$ Italy ${ }^{39}$, another Grand Chamber, unanimously, confirmed that interpretation of the ECHR. ${ }^{40}$ Likewise in the more recent case of De Souza Ribeiro $v$ France ${ }^{41}$, the Grand Chamber was united in confirming these three Articles as the textual foundation of the principle. ${ }^{42}$ As the Court has noted there is a logical connection between these Articles in the creation of the principle of subsidiarity. States party to the ECHR voluntarily bind themselves to guarantee the rights and freedoms specified in the Convention and to provide an effective domestic remedy to persons whose protected rights/freedoms have been infringed. Victims of such breaches will only be allowed to avail themselves of international redress before the Court if they have previously sought, unsuccessfully, to obtain a remedy before the relevant domestic authorities (normally via the national judicial system). We have already observed how former President Costa has identified Article 35(1) as being at the core of the Convention's principle of subsidiarity. ${ }^{43}$

Article 19 of the ECHR (establishment of the Court) has also been held to provide a foundation for subsidiarity by the Grand Chamber in Austin and Others $v U K^{44}$.

\footnotetext{
${ }^{37}$ Judgment of 26 October 2000.

38 Ibid. at para. 152.

39 Judgment of 29 March 2006.

${ }^{40}$ Ibid. at para. 28.

${ }^{41}$ Judgment of 13 December 2012.

${ }^{42}$ Ibid. at para. 77.

${ }^{43}$ Supra n. 26.

${ }^{44}$ Judgment of 15 March 2012.
} 
Subsidiarity is at the very basis of the Convention, stemming as it does from a joint reading of Articles 1 and 19. The Court must be cautious in taking on the role of a first-instance tribunal of fact, where this is not rendered unavoidable by the circumstances of a particular case. As a general rule, where domestic proceedings have taken place, it is not the Court's task to substitute its own assessment of the facts for that of the domestic courts and it is for the latter to establish the facts on the basis of the evidence before them. Though the Court is not bound by the findings of domestic courts and remains free to make its own appreciation in the light of all the material before it, in normal circumstances it requires cogent elements to lead it to depart from the findings of fact reached by the domestic courts... ${ }^{45}$

Hence recognition of the Court's inherent limitations as a fact-finding body, usually dealing with allegations about events having occurred many years previously, together with the primary responsibilities of domestic authorities to secure and provide redress for breaches of Convention rights/freedoms as elaborated above underpin this aspect of the principle of subsidiarity.

\section{The Court's utilisation of the principle of subsidiarity}

We will now examine the different ways in which the Court has made use of the principle. As an important theme of our study is to determine if that usage has altered over time, especially during the contemporary period of heightened State emphasis on subsidiarity, we shall divide the jurisprudence into three eras. The first covers the original Court's utilisation of subsidiarity. The second era encompasses the full-time Court's usage between its' coming into existence ${ }^{46}$ and the Interlaken Conference/Declaration ${ }^{47}$. The third era is the post-Interlaken period.

(i) The Original Court's usage

Petzold has provided us with an innovative study of the original Court's (and European Commission of Human Rights') use of subsidiarity. ${ }^{48}$ He discovered that in one of its earliest judgments the Court referred to the principle when demarcating the responsibilities of Contracting States and the Court. In determining if a breach of Article 14 (prohibition of discrimination) in conjunction with Article 2 of Protocol No. 1 (right to education) had occurred, the Plenary Court ruled that:

In attempting to find out in a given case, whether or not there has been an arbitrary distinction, the Court cannot disregard those legal and factual features which characterise the life of the society in the State which, as a Contracting Party, has to answer for the measure in dispute. In so doing it cannot assume the rôle of the competent national authorities, for it would thereby lose sight of the subsidiary nature of the international machinery of collective enforcement established by the

\footnotetext{
${ }^{45}$ lbid. at para. 61

${ }^{46}$ In November 1998.

4719 February 2010.

${ }^{48}$ Supra n. 36.
} 
Convention. The national authorities remain free to choose the measures which they consider appropriate in those matters which are governed by the Convention. Review by the Court concerns only the conformity of these measures with the requirements of the Convention. ${ }^{49}$

This led Petzold to identify two elements in the use of subsidiarity by the ECHR system. A procedural aspect, which embodied the requirement for applicants to exhaust domestic remedies before lodging complaints at Strasbourg and a substantive limb. The latter element was composed of three strands in the subsequent case-law where the original Court would limit its review of domestic authorities' decisions in accordance with the principle of subsidiarity. First, the Court would not seek to supplant domestic courts' primary role in delivering interpretations of national law. "It is in no way the task of the European Court of Human Rights to take the place of the competent national courts in the interpretation of domestic law..." ${ }^{50}$ Secondly, where the Convention placed "a duty of specific conduct on the part of the competent national authority". ${ }^{51}$ Petzold gave as an example the judgment in Wemhoff $v$ Germany ${ }^{52}$, where the original Court left it up to the respondent State to provide the reasons justifying the applicant's detention on remand when determining if there had been a breach of ECHR Article 5(3). Thirdly, through the Court's creation of the margin of appreciation doctrine.

This margin of appreciation thus stems directly from the principle of subsidiarity as it applies within the Convention system. Its basis is, according to the Court, the clear understanding that the Convention leaves to each Contracting State in the first place the task of securing within the domestic legal order the rights and freedoms which it enshrines: the Convention institutions make their own contribution to this task but they become involved only through contentious proceedings and once all domestic remedies have been exhausted. The doctrine of the margin of appreciation is a natural product of the principle of subsidiarity; it is a technique developed to allocate decision-making authority to the proper body in the Convention scheme, to delineate in concrete cases the boundary between "primary" national discretion and the "subsidiary" international supervision. ${ }^{53}$

He identified Handyside $v U K^{54}$, as a leading authority to support this proposition. Prophetically Petzold concluded by observing that the principle of subsidiarity within the

\footnotetext{
${ }^{49}$ Case "Relating To Certain Aspects of the Laws on the Use of Languages in Education in Belgium" v Belgium (Merits) ("Belgian Linguistic"), Judgment of 23 July 1968, at p.31 para. 10.

${ }^{50} X$. and $Y . v$ The Netherlands, Judgment of 26 March 1985 at para. 29. For another aspect of this crucial judgment see, A. Mowbray, The Development of Positive Obligations under the ECHR by the ECtHR, (Oxford: Hart Pub., 2004) at p.127.

${ }^{51}$ Supra n. 36 at p. 52.

52 Judgment of 27 June 1968.

${ }^{53}$ Supra n. 36 at p. 59.

${ }^{54}$ Judgment of 7 December 1976. See also A. Mowbray, Cases, Materials \& Commentary on the ECHR $3^{\text {rd }}$ ed (Oxford: OUP. 2012) at p.633-637 for discussion of the margin of appreciation doctrine.
} 
ECHR system was not static but evolving. Therefore, we shall now examine how the "new" full-time Court embraced the principle.

(ii) The full-time Court's usage prior to Interlaken

Under the Protocol 11 revised enforcement system the "new" Court absorbed the function of determining the admissibility of applications from the European Commission. ${ }^{55}$ However, the Court continued the Commission's earlier approach of strictly applying the exhaustion of domestic remedies admissibility criterion. "The Court recalls that the rule of exhaustion of domestic remedies referred to in Article 35(1) of the Convention obliges applicants first to use the remedies that are normally available and sufficient in the domestic legal system to enable them to obtain redress for the breaches alleged. ${ }^{\prime 56}$ Also, the full-time Court reaffirmed its predecessor's view that States had the predominant duty of safeguarding Convention rights and freedoms. As the unanimous Grand Chamber stated in Christine Goodwin v UK, "[i]n accordance with the principle of subsidiarity, it is indeed primarily for the Contracting States to decide on the measures necessary to secure Convention rights within their jurisdiction". ${ }^{57}$ But, dissenters in high profile cases sometimes criticised their majoritarian colleagues for ignoring the principle of subsidiarity. For example, in Ocalan $v$ Turkey $^{58}$, the Grand Chamber was divided on the issue of whether the applicant's trial before a special national security court satisfied the requirement, under Article 6(1) of the ECHR, of being an independent and impartial tribunal. For the majority the presence, during the early stages of the trial, of a military judge undermined the independence of the trial. Whereas the President of the Court together with his successor and four other judges dissented as they believed that Turkey had complied with its Article 6(1) obligations by swiftly introducing constitutional changes removing military judges from national security courts following an adverse judgment by the Court in another case.

Inherent in a system based on the principle of subsidiarity is loyal cooperation between a supranational judicial body, such as this Court, and the States which have adhered to the system. Imposing standards that are too high does not appear to us to be the best way of encouraging such cooperation or of expressing satisfaction to the States that provide it. ${ }^{59}$

This observation vividly demonstrates that senior members of the full-time Court saw subsidiarity as a means of promoting State compliance and support for the Convention

\footnotetext{
${ }^{55}$ Protocol No. 11 to the Convention for the Protection of Human Rights and Fundamental Freedoms, Restructuring the Control Machinery Established Thereby, ETS no. 155, Strasbourg 11 May 1994 and see Ibid. Mowbray at p. 13.

${ }^{56}$ Isayeva, Yusupova, Bazayava v Russia, Judgment of 24 February 2005 at para. 144.

57 Judgment of 11 July 2002 at para. 85.

58 Judgment of 12 May 2005.

${ }^{59}$ Ibid. Joint Partly Dissenting Opinion of Judges Wildhaber, Costa, Caflisch, Turmen, Garlicki and Borrego Borrego at para. 9.
} 
by taking account of how a respondent State has reacted to previous judgments when determining if a breach has occurred in a later complaint. In Ocalan the dissenters were willing to overlook the initial membership of a military judge in the applicant's trial as Turkey was in the process of implementing an earlier ruling by the Court and the dissenters wished to acknowledge that positive outcome.

The Grand Chamber also reaffirmed that ideally domestic courts, or other suitable judicial authorities, should determine the facts of disputed cases before an application is lodged at Strasbourg. "[I]n line with the principle of subsidiarity, it is best for the facts of cases to be investigated and issues to be resolved in so far as possible at the domestic level. ${ }^{\prime 60}$ This was a clear recognition of the institutional, and budgetary, limitations of the Court as an international judicial supervisory mechanism and not a court of first instance hearing witnesses and determining evidential disputes. Of course, the Court has the power, under Article 38 of the ECHR, to conduct a fact-finding "investigation" if it determines such a procedure is necessary. However, as Professor Leach and his colleagues discovered the full-time Court had reduced the number of such investigations it launched (18) compared to the original Court and Commission (which had held them in 74 cases). They concluded that saving "time and costs" were major considerations for the Court. ${ }^{61}$ We can see the resource implications for those, rare, cases where the Court invokes its fact-finding powers in the Grand Chamber's determination of Ilascu and Others $v$ Moldova and Russia ${ }^{62}$. In order to discover the nature and extent of the applicants' (severe) mal-treatment by the self-proclaimed "Moldavian Republic of Transdniestria" authorities, supported by Russia, the Grand Chamber designated four of its judges as delegates who went and heard 43 witnesses, including the imprisoned applicants. Clearly it would have saved the Court these efforts if there had been a through and impartial domestic determination of the facts, but that was obviously not realistic in this contested and problematic region. ${ }^{63}$ So it is essential that the Court can have resort to its investigatory power in suitable cases. Generally, however, the principle of subsidiarity as applied to fact-finding relieves the Court of these onerous responsibilities. Thereby, revealing that the principle has benefits for both States and the Court.

The full-time Court announced a major change in its approach to Article 13 of the ECHR in Kudla $v$ Poland ${ }^{64}$, relying heavily on the principle of subsidiarity to provide a jurisprudential justification for the new interpretation. The key issue was whether complainants alleging excessive delays in the domestic courts determinations of their "civil rights" or "criminal charges" against them, which if upheld would violate Article $6(1)$ of the ECHR, were also able to invoke Article 13 to allege a separate breach of the right to an effective domestic remedy where there was no domestic mechanism to deal

\footnotetext{
${ }^{60}$ Varnava and Others v Turkey, Judgment of 18 September 2009.

${ }^{61}$ P. Leach et al., International Human Rights and Fact Finding, (London: London Metropolitan University/Nuffield Foundation, 2009) at p. 80.

62 Judgment of 8 July 2004.

${ }^{63}$ See A. Mowbray, "European Court of Human Rights: May 2012-April 2013" 19(4) Eur. Pub. L. (2013) at p. 646 for an analysis of more recent litigation involving "Transdniestria".

${ }^{64}$ Supra n. 37.
} 
with complaints of excessive delays in the national judicial system. The original Court had developed the practice of not examining Article 13 complaints in such cases where it had found a breach of the right to a judicial determination within a reasonable time enshrined in Article 6(1), on the basis that it was not necessary to also examine Article 13. ${ }^{65}$ However, the Grand Chamber ruled that:

In the Court's view, the time has come to review its case-law in the light of the continuing accumulation of applications before it in which the only, or principal, allegation is that of a failure to ensure a hearing within a reasonable time in breach of Article $6 \S 1$.

The growing frequency with which violations in this regard are being found has recently led the Court to draw attention to "the important danger" that exists for the rule of law within national legal orders when "excessive delays in the administration of justice" occur "in respect of which litigants have no domestic remedy" (see, for example, Bottazzi v. Italy [GC], no. 34884/97, § 22, ECHR 1999V...66

The Grand Chamber considered that Article 13, based on the primary obligation of Contracting States to protect Convention rights within their own legal systems, reinforced States' duties under Article 6. Furthermore:

If Article 13 is, as the Government argued, to be interpreted as having no application to the right to a hearing within a reasonable time as safeguarded by Article $6 \S 1$, individuals will systematically be forced to refer to the Court in Strasbourg complaints that would otherwise, and in the Court's opinion more appropriately, have to be addressed in the first place within the national legal system. In the long term the effective functioning, on both the national and international level, of the scheme of human rights protection set up by the Convention is liable to be weakened. ${ }^{67}$

Consequently, subject to one dissent, the Grand Chamber determined that Article 13 was also applicable to the applicant and had been violated as he did not have an effective remedy in Poland to challenge the excessive delay in the fraud case brought against him.

The judgment in Kudla represented a completed reversal of the original Court's interpretation and application of Article 13, primarily motivated by the growing case-load crisis facing the new full-time Court. ${ }^{68}$ But the judgment vividly revealed how the Court

\footnotetext{
${ }^{65}$ For example, Pizzetti v Italy, Judgment of 26 February 1993.

${ }^{66}$ Supra n. 37 at para. 148. More generally on the topic of the Court altering its interpretation of the Convention see, A. Mowbray, "An Examination of the European Court of Human Rights' Approach to Overruling its Previous Case law", 9(2) H.R.L.R. 179 (2009)

${ }^{67}$ Ibid. at para. 155 .

${ }^{68}$ Less than a year after the coming into existence of the full-time Court its President had issued a press release expressing concern about the "daunting" and ever rising numbers of complaints being lodged with the Court: President Wildhaber, Strasbourg, June 1999.
} 
was able to utilise the principle of subsidiarity to underpin its new approach. So we see another situation where subsidiarity was of benefit to the Court in maximising the allocation of its precious resources, as States were placed under a clear Convention duty to establish effective domestic mechanisms to deal with complaints of excessive delays in national court proceedings. Sadly hindsight discloses that Kudla has not resolved the systemic problem of various States failing to operate efficient judicial systems. ${ }^{69}$

Another major development in the full-time Court's response to complaints alleging a systematic failure in Contracting States to respect the Convention's guarantees was the development of pilot judgments. In 2004 the Committee of Ministers, acting on a proposal from the Court, issued a Resolution encouraging the Court in judgments finding a breach of the ECHR to identify any "underlying systemic problem and the source of this problem, in particular when it is likely to give rise to numerous applications, so as to assist States in finding the appropriate solution and the Committee of Ministers in supervising the execution of judgments. ${ }^{70}$ Whilst the Court has been cautious in delivering pilot judgments ${ }^{71}$, those that have been accorded this special designation have dealt with serious violations affecting many people, such as the defective rent control legislation which governed the relationships between about 900,000 tenants and their 100,000 landlords in Hutten-Czapska $v$ Poland ${ }^{72}$. In recent times the Court has acknowledged a connection between the pilot judgment procedure and the principle of subsidiarity.

Another important aim of the pilot-judgment procedure is to allow the speediest possible redress to be granted at domestic level to the large numbers of people suffering from the general problem identified in the pilot judgment, thus implementing the principle of subsidiarity which underpins the Convention system (see Burdov v. Russia (no. 2), no. 33509/04, §§ 127 and 142, ECHR 2009, and Greens and M.T. V. the United Kingdom, nos. 60041/08 and 60054/08, § 108, ECHR 2010 (extracts)). It may thus be decided in the pilot judgment that the proceedings in all cases stemming from the same problem should be adjourned pending the implementation of the relevant measures by the respondent State. ${ }^{73}$

So, again, we see in the different context of the pilot judgment process that subsidiarity has been invoked to underpin a new approach by the Court that is designed to help diverse participants in the Strasbourg complaints system, including successful complainants (and potential complainants) receiving swifter redress, respondent States and the Committee of Ministers gaining the insights of the Court on the nature of the systemic problem and the Court in being potentially relieved from having to determine numerous individual complaints generated by the identified systemic problem.

\footnotetext{
${ }^{69}$ See, Mowbray supra n. 54 at pp-431-434.

${ }^{70} \operatorname{Res}(2004) 3$.

${ }^{71}$ Only 6 were expressly identified as pilot judgments by 2010 according to P. Leach et al., Responding to Systematic Human Rights Violations, (Antwerp: Intersentia, 2010) p.*** 174.

72 Judgment of 19 June 2006.

${ }^{73}$ Kuric and Others v Slovakia, Just Satisfaction Judgment of 12 March 2014 at para. 134.
} 
Applicants raised the principle of subsidiarity to challenge the respondent government's unusual strategies of seeking to raise a defence (arguably) not asserted before the domestic courts and contesting the decision of their highest court in $A$ and Others $v U K^{74}$. The case involved the controversial response of the UK to the al'Qaeda attacks in America during September 2001. Within a few weeks of those attacks the British government introduced legislative proposals, enacted as the Anti-Terrorism, Crime and Security Act 2001, and notified the Council of Europe of a derogation, made under Article 15 of the ECHR, regarding the Act's powers concerning the detention of foreign nationals believed to pose a terrorist threat to the security of the UK. The applicants were detained under those powers, as they could not be deported to their home States due to a well- founded fear that they would be subjected to maltreatment, falling within Article 3 of the Convention, if returned to those countries. ${ }^{75}$ The applicants challenged their detention under the 2001 Act and eventually the House of Lords granted a quashing order regarding the derogation and issued a declaration of incompatibility, under section 4 of the Human Rights Act 1998, in respect of the detention power contained in the 2001 Act. $^{76}$ A majority of the House held those provisions were disproportionate and involved discrimination against foreign nationals. Nevertheless, most of the applicants continued to be held in detention. At Strasbourg the applicants claimed they were victims of breaches of several Convention Articles. Their complaints were relinquished, under ECHR Article 30, to the Grand Chamber. Before that body the government, inter alia, sought to defend the applicants' detention as falling within the permissible ground that they were being held whilst action was being taken with a view to their deportation (authorised by Article 5(1)(f) of the Convention). In response the applicants submitted that, "it was abusive and contrary to the principle of subsidiarity for the Government to raise a novel argument before the Court and that they should be stopped from so doing. ${ }^{\prime 77}$ The Grand Chamber, unanimously, ruled that:

The Court is intended to be subsidiary to the national systems safeguarding human rights. It is, therefore, appropriate that the national courts should initially have the opportunity to determine questions of the compatibility of domestic law with the Convention and that, if an application is nonetheless subsequently brought before the Court, it should have the benefit of the views of the national courts, as being in direct and continuous contact with the forces of their countries... It is thus of importance that the arguments put by the Government before the national courts should be on the same lines as those put before this Court. In particular, it is not open to a Government to put to the Court arguments which are inconsistent with the position they adopted before the national courts... ${ }^{78}$

However, the Grand Chamber did not accept that the British government had infringed these limitations as it had addressed the relevance of Article 5 during the domestic

\footnotetext{
74 Judgment of 15 February 2009.

75 The Court had previously so held in Chahal v UK, judgment of 15 November 1996 and see Mowbray supra. n.54 at p. 204.

${ }^{76}$ A. v Secretary of State for the Home Department [2004] UKHL 56.

${ }^{77}$ Supra n. 74 at para. 140.

78 Ibid. at para. 154.
} 
proceedings and most of the members of the House of Lords had expressly or implicitly examined whether the applicants' detention was justified under the Article 5(1) exceptions. Regarding the applicants' argument that the respondent government should not be permitted to dispute the House of Lords' ruling that the British derogation was disproportionate because; "it would be inconsistent with Article 19 and the principle of subsidiarity for the Court to be asked by a Government to review alleged errors of fact or law committed by that Government's own national courts."79 The government responded that whilst they "accorded very great respect" ${ }^{\prime \prime 0}$ to the House of Lords' decision and the 2001 detention powers had been repealed, once the case had been brought before the Court the government believed that it was necessary to query the reasoning of the House. The Grand Chamber observed that:

The present situation is, undoubtedly, unusual in that Governments do not normally resort to challenging, nor see any need to contest, decisions of their own highest courts before this Court. There is not, however, any prohibition on a Government making such a challenge, particularly if they consider that the national supreme court's ruling is problematic under the Convention and that further guidance is required from the Court. ${ }^{81}$

Nevertheless, the Grand Chamber went on to demonstrate support for the House of Lords by holding that where a supreme court had found a national derogation did not meet the requirements of ECHR Article 15, then the Court would be very reluctant to disagree with that determination.

The object and purpose underlying the Convention, as set out in Article 1, is that the rights and freedoms should be secured by the Contracting State within its jurisdiction. It is fundamental to the machinery of protection established by the Convention that the national systems themselves provide redress for breaches of its provisions, with the Court exercising a supervisory role subject to the principle of subsidiarity ( $Z$. and Others $v$. the United Kingdom, no. 29392/95, § 103, ECHR $2001-V)$. ...where the highest domestic court has examined the issues relating to the State's derogation and concluded that there was a public emergency threatening the life of the nation but that the measures taken in response were not strictly required by the exigencies of the situation, the Court considers that it would be justified in reaching a contrary conclusion only if satisfied that the national court had misinterpreted or misapplied Article 15 or the Court's jurisprudence under that Article or reached a conclusion which was manifestly unreasonable. ${ }^{82}$

The Grand Chamber went on, unanimously, to concur with the House of Lords' view that the British derogative was disproportionate (in its unjustified discrimination between foreign and national suspected terrorists) and that a number of the applicants had, inter alia, suffered violations of their right to liberty.

\footnotetext{
${ }^{79}$ Ibid. at para. 142.

${ }^{80}$ Ibid. at para. 150.

${ }^{81}$ Ibid. at para. 157.

${ }^{82}$ Ibid. at para. 174.
} 
The above judgment is of great significance in the full-time Court's development of the principle of subsidiarity as it discloses the Strasbourg judges' reaction to a respondent government seeking to utilise the Court as a de facto appellate tribunal in relation to a national supreme court. Such a scenario is rare because if an individual wins his/her Convention based challenge to state action before the highest national court that is normally the end of the process. It is only in the limited type of scenario, as in $A$ and Others, that success before the highest national court does not provide an effective remedy that the individual will then take his/her case on to Strasbourg. In such a situation the Grand Chamber ruled that whilst the respondent State would not be allowed to raise arguments contrary to those it had deployed before the domestic courts, the State could seek to challenge the supreme court's application of Convention jurisprudence. But as the Grand Chamber reasoning demonstrated the Court would be reluctant to disagree with a supreme court's judgment that a breach of the Convention had occurred. By adopting that approach the Grand Chamber was firmly supporting national courts decision-making which was in accordance with Strasbourg case-law.

Another important facet of the judgment in $A$ and Others concerned the role of the margin of appreciation doctrine, which as we have noted above Petzold identified as being derived from the principle of subsidiarity. The British government argued before the Grand Chamber that the House of Lords had failed to grant the executive and Parliament a sufficiently wide margin of appreciation to determine whether it was necessary for the applicants to be detained in order to protect the UK from international terrorism. The Grand Chamber responded that:

The doctrine of the margin of appreciation has always been meant as a tool to define relations between the domestic authorities and the Court. It cannot have the same application to the relations between the organs of State at the domestic level. ${ }^{83}$

Consequently, as the House of Lords had carefully examined the proportionality of the applicants' detention the Grand Chamber rejected the government's contention that insufficient consideration had been accorded to the opinions of the executive or legislature. Therefore, the Grand Chamber has made clear that the Strasbourg margin of appreciation doctrine is an international jurisprudential tool for demarcating State and Court responsibilities in the application of the Convention, not a domestic public law mechanism.

(iii) The full-time Court's usage post Interlaken

It is generally appreciated that the Interlaken "High Level Conference on the Future of the European Court of Human" convened by the Swiss government on 18 and 19 February 2010 at the request of Jean-Paul Costa, the Court's President, was designed to gain express political support for the Court and agreement about further reforms to the ECHR system from the State parties. ${ }^{84}$ The resultant Declaration and Action Plan ${ }^{85}$ gave

\footnotetext{
83 Ibid. at para. 184.

${ }^{84}$ For a detailed study of the background to the conference and its outcomes see, A. Mowbray, "The Interlaken Declaration- The Beginning of A new Era for the European Court of Human Rights?", 10(3) H.R.L.R. 519(2010).
} 
high prominence to the principle of subsidiarity. The States early in the Declaration stressed, "the subsidiary nature of the supervisory mechanism established by the Convention and notably the fundamental role which national authorities, i.e. governments, courts and parliaments, must play in guaranteeing and protecting human rights at the national level". ${ }^{86}$ The Conference called for "a strengthening of the principle of subsidiarity". ${ }^{87}$ Furthermore, the Action Plan invited the Court to

(a) avoid reconsidering questions of fact or national law that have been considered and decided by national authorities, in line with its case-law according to which it is not a fourth instance court;

(b) apply uniformly and rigorously the criteria concerning admissibility and jurisdiction and take fully into account its subsidiary role in the interpretation and application of the Convention... ${ }^{88}$

Two years later the British government organised the Brighton Conference ${ }^{89}$ of State parties that resulted in the Brighton Declaration ${ }^{90}$. Again the States affirmed their and the Court's shared "responsibility for realising the effective implementation of the Convention, underpinned by the fundamental principle of subsidiarity. ${ }^{\prime 11}$ They welcomed "the development by the Court in its case law of principles such as subsidiarity and the margin of appreciation, and encourage[d] the Court to give great prominence to and apply consistently these principles in its judgments". ${ }^{92}$ And, as we noted at the start of this article, the States decided that "for reasons of transparency and accessibility" ${ }^{13}$ a reference to the principle of subsidiarity should be added to the ECHR's Preamble.

These international conferences of State parties created the contemporary political ${ }^{94}$ climate within which the Court now has to apply the principle of subsidiarity so we shall examine the jurisprudence to see if the usage has been in accordance with the Declarations.

In Austin and Others $v U K^{95}$, the Grand Chamber was faced with complaints about the Metropolitan Police force's controversial tactic of "kettling" demonstrators and

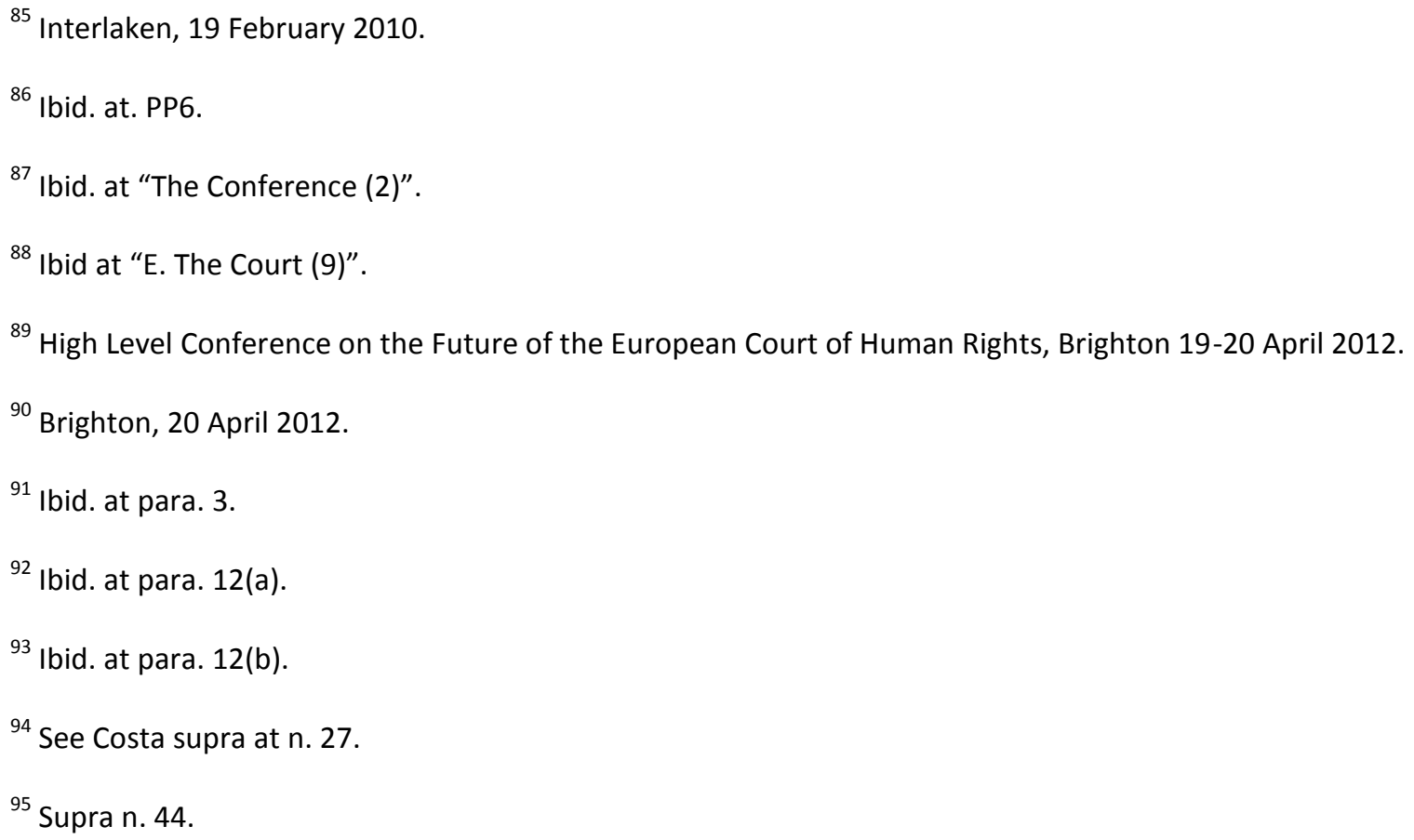


bystanders located in places where the police feared serious public disorder. Kettling involved the police keeping such persons within a police cordon (with many police officers equipped with shields and wearing protective helmets) until the police determined that the threat of public disorder had abated. On $1^{\text {st }}$ May (May Day) 2001 the Metropolitan Police had been notified of two events in London and police intelligence indicated that other events were planned, including protests by 500-1000 "hard-core" demonstrators seeking violent confrontations. On the previous May Day there had been extensive violent protests in London. In the early afternoon of May Day 2001 the police decided to introduce a police cordon around people in Oxford Circus as the police feared the occurrence of violent protest (under domestic law the police were seeking to prevent a breach of the police). Up to 2,000 persons were kept within the police cordon. Over seven hours the police gradually allowed persons within the cordon to leave in groups. The four applicants, a protestor, a person who had gone to the area to buy a book and two local workers who were caught up in the cordon during their lunch breaks, unsuccessful challenged the lawfulness of their subjection to kettling before the domestic courts. At Strasbourg they alleged the police had violated their right to liberty (Article 5 ECHR). The British government responded that, as the House of Lords had unanimously concluded ${ }^{96}$, the police action against the applicants had not resulted in a deprivation of their liberty so no breach of Article 5 had occurred. Regarding the events of May Day 2001 the Grand Chamber, as we have previously noted ${ }^{97}$, expressly applied the principle of subsidiarity to the process of fact finding. Given that the High Court hearing of the applicants' case had lasted three weeks, during which six days had been devoted to oral evidence and the trial judge had been shown video footage of the incident and examined thousands of pages of evidence with his judgment containing 500 paragraphs devoted to the evidence and his findings of fact, the Grand Chamber found "no ground to depart from them". ${ }^{98}$ A large majority of the Grand Chamber (fourteen votes to three) concluded, similarly too the House of Lords, that the applicants had not suffered a deprivation of liberty and therefore no breach of Article 5 had occurred. The majority emphasised that this conclusion was "based on the specific and exceptional facts of this case." ${ }^{\prime 99}$

Austin represents a clear example of the Grand Chamber complying with the Interlaken Action Plan's invitation for the Court not to reconsider questions of fact decided at the national level. ${ }^{100}$ Where there has been such an extensive examination of the disputed facts by an independent and impartial domestic court it would not only be contrary to the principle of subsidiarity but a waste of the Court's precious resources for the latter to try and substitute itself as the primary fact-finding tribunal. However, where domestic authorities have failed to engage in robust judicial fact-finding then the Court is

\footnotetext{
${ }^{96}$ Austin v Commissioner of Police of the Metropolis [2009] UKHL 5.

${ }^{97}$ Supra n. 45.

${ }^{98}$ Supra n.44 at para. 62.

${ }^{99}$ Ibid. at para. 68.

${ }^{100}$ Supra n. 88.
} 
obliged to undertake that task itself. A very dramatic example of such a failure necessitating the Court to become the primary fact finder occurred a few months later in El-Masri $v$ The Former Yugoslav Republic of Macedonia ${ }^{101}$. This was the first occasion where the Court was faced with a complainant alleging that a Contracting State had violated the Convention through its collaboration with the United States of America's secret "extraordinary rendition"102 programme instigated as a response to the September 2001 al'Qaeda terrorist attacks in that country. ${ }^{103}$ The German applicant contended that he had, inter alia, been forcibly detained by respondent State officials in a hotel, handed over to USA personnel in Macedonia who subjected him to torture and then transported him to an unacknowledged Central Intelligence Agency detention facility, located in a former brick works outside Kabul in Afghanistan. There he was subjected to harsh interrogations during four months of detention before being flown back to Europe and released in the Albanian countryside! The respondent government categorically denied the applicant's allegations and instead claimed that Macedonian officials had merely checked his passport when he entered the country and that he had voluntarily left for Serbia three weeks later. Whilst the Grand Chamber acknowledged that it was "sensitive to the subsidiary nature of its role and recognises that it must be cautious in taking on the role of a first-instance tribunal of fact, where this is not rendered unavoidable by the circumstances of a particular case ${ }^{104}$, it had to take into account the quality of the domestic fact-finding procedures. Here the Skopje public prosecutor had rejected the applicant's criminal complaint after two months, during which time the prosecutor had not interviewed the applicant or hotel staff nor investigated specified aircraft landings in the country. Also the applicant's civil action against the government had been ongoing since 2009 with no judgment delivered by the time of the Grand Chamber proceedings. Consequently, the Grand Chamber, unanimously, went on to find that the respondent State had not provided a plausible explanation of what had happened to the applicant and that his account, with supporting evidence, was established beyond reasonable doubt. This led to determinations that the respondent State had, inter alia, subjected El-Masri to inhuman and degrading treatment during his unlawful detention in the hotel, been responsible for his torture by American officials at Skopje airport and breached Article 5 through Macedonia's liability for his captivity in Afghanistan at the hands of the Americans. Therefore, El-Masri powerfully illustrates that the principle of subsidiarity, so keenly invoked by States during the above Conferences, imposes obligations upon Contracting States (in that context the need for robust domestic fact-finding) and it is not simply a device to constrain the Court.

\footnotetext{
101 Judgment of 13 December 2012 and for a detailed examination of this case see, A. Mowbray supra n.63 at p. 649.

102 Defined by the Court as involving "an extra-judicial transfer of persons from one jurisdiction or State to another, for the purposes of detention and interrogation outside the normal legal system, where there was a real risk of torture or cruel, inhuman or degrading treatment". Ibid. at para. 221.
}
${ }^{103}$ For the work of other Council of Europe bodies in regard to this programme see A. Mowbray supra n.54 at pp.257-259. More recently the Court has upheld complaints against Poland for its involvement in the programme: Al Nashiri v Poland and Husayn (Abu Zubaydah) v Poland, Judgments of 24 July 2014.

${ }^{104}$ Supra n.101 at para. 155. 
Another facet of the principle of subsidiarity placing duties on domestic authorities was highlighted by the Grand Chamber in Fabris v France ${ }^{105}$. The applicant, who had been formally recognised as an "illegitimate" child of a married woman by a domestic court, complained about his inability to enforce inheritance rights (compared to those of his legitimate half-siblings) alleging discrimination contrary to, inter alia, Article 14 (prohibition of discrimination in conjunction with Article 1 of Protocol No. 1 (protection of property) of the ECHR. The Grand Chamber was united in holding that, "where an applicant's pleas relate to the "rights and freedoms" guaranteed by the Convention the courts are required to examine them with particular rigour and care and that this is a corollary of the principle of subsidiarity". ${ }^{106}$ Noting that the original Court had ruled against discrimination based upon illegitimacy decades previously ${ }^{107}$ the Grand Chamber was critical of the French courts' treatment of the applicant's inheritance claim due to his birth status. Consequently, the Grand Chamber found he had suffered a breach of Article 14 in conjunction with Article 1 of Protocol No. 1. Hence, domestic courts should pay attention to the Court's established jurisprudence when dealing with relevant claims as an element of subsidiarity. Such a requirement is fully in conformity with States' express acknowledgment of their shared responsibility for the effective implementation of the Convention in the Brighton Declaration. ${ }^{108}$

The contemporary high profile of the principle of subsidiarity within the ECHR system was further demonstrated by thirty three Members of the European Parliament invoking it as a basis for their intervention in the Grand Chamber case of Lautsi and Others $v$ Italy $^{109}$. The applicants, a mother and her two children, complained that the legal requirement for Italian state schools to display crucifixes on classroom walls violated their Convention rights, inter alia, including the right to education (Article 2 of Protocol No. 1). The MEPs argued that, "the Court was not a constitutional court and had to respect the principle of subsidiarity and recognise a particularly broad margin of appreciation in favour of Contracting States not only regarding the relationship between the State and religion but also where they carried out their functions in the area of education and teaching." 110 Finding no European consensus regarding the display of religious symbols in state schools the Grand Chamber went on to hold that issue fell within the margin of appreciation of States and Italy had not acted outside that discretion. Lautsi was yet another judgment disclosing the intertwined connections between subsidiarity and the margin of appreciation in the reasoning of the Court. Furthermore, the Grand Chamber revealed its reluctance to declare an established practice reflecting a particular State's religious heritage as being contrary to the

\footnotetext{
105 Judgment of 7 February 2013.

106 Ibid. at para. 72.

${ }^{107}$ In Marckx v Belgium, Judgment of 13 June 1979.

${ }^{108}$ Supra n. 91.

109 Judgment of 18 March 2011. For an examination of the earlier Chamber judgment see, C. Panara, "Lautsi v Italy: The Display of Religious Symbols by the State", 17(1) Eur. Pub. L. 139 (2011).

${ }^{110}$ Ibid. at para. 56 .
} 
Convention, that attitude most certainly accorded with the States' ethos of the principle of subsidiarity embodied in the Interlaken and Brighton Declarations.

An even more recent example of the Court applying the principle of subsidiarity and its offspring the margin of appreciation in the context of a dispute involving religious beliefs was S.A.S. $v$ France ${ }^{111}$. The applicant was a French national, who had been born in Pakistan and was brought up in a Sunni cultural tradition in which it was customary for women to wear a full-face veil in public. As a devout adult Muslim she wished, of her own volition, to wear a burqa (full-body covering with a mesh over the face) and niqab (a full-face veil with just an opening for the eyes) in public on occasions that she chose (for example during Ramadan). However, in October 2010 a Law was enacted by the French Parliament that made it a criminal offence for persons to wear clothing designed to conceal their faces in public places, which were defined to include public authority premises such as schools and hospitals. Breach of the Law could result in a maximum fine of 150 euros and/or an obligation to attend a citizenship course. The Law had been introduced because the government, inter alia, considered that facial concealment in public places was contrary to the French Republican value of "fraternity" and it also fell below the "minimum requirement of civility that is necessary for social interaction".112 The Law had been enacted with only one vote against and four abstentions in the National Assembly and the Senate. The Constitutional Council considered, with a reservation regarding places of worship, that the Law was compliant with the Constitution. Before the Grand Chamber the applicant submitted that the Law violated her right to respect for her private life (regarding her desired appearance) under Article 8 and her freedom to manifest her religious beliefs guaranteed by Article 9 of the Convention. The Grand Chamber found that the applicant's complaints fell within both of those Articles, but the latter was given greater attention due to the applicant's religious beliefs. When assessing if the Law was "necessary in a democratic society" the Grand Chamber noted that:

It is also important to emphasise the fundamentally subsidiary role of the Convention mechanism. The national authorities have direct democratic legitimation and are, as the Court has held on many occasions, in principle better placed than an international court to evaluate local needs and conditions. In matters of general policy, on which opinions within a democratic society may reasonably differ widely, the role of the domestic policy-maker should be given special weight (see, for example, Maurice v. France [GC], no. 11810/03, § 117, ECHR 2005-IX). This is the case, in particular, where questions concerning the relationship between State and religions are at stake (see, mutatis mutandis, Cha'are Shalom Ve Tsedek, cited above, $\S 84$, and Wingrove v. the United Kingdom, 25 November 1996, § 58, Reports 1996-V; see also Leyla Şahin, cited above, § 109). As regards Article 9 of the Convention, the State should thus, in principle, be afforded a wide margin of appreciation in deciding whether and to what extent a limitation of the right to manifest one's religion or beliefs is "necessary". ${ }^{113}$

\footnotetext{
${ }^{111}$ Judgment of 1 July 2014.

112 Ibid. at para. 25.

113 Ibid. at para. 129.
} 
After emphasising that whether to ban full-face veils in public places was a "choice of society"114 and that the Court had to "exercise a degree of restraint"115 when reviewing the balance struck by the democratic process in France, a large majority of the Grand Chamber (fifteen votes to two) concluded that there had been no breaches of Articles 8 or 9 of the ECHR. For the majority the respondent State could justify the restrictions imposed on the applicant as being for the legitimate aim of protecting the rights of others by preserving the French social value of "living together". Judges Nussberger and Jaderblom dissented opining, in part, that the latter "concept seems far-fetched and vague". ${ }^{116}$ This study is not the place to examine that dispute. However, for us the judgment in S.A.S. provides a striking contemporary demonstration of the Court following the "democracy-enhancing approach" elaborated in Judge Spano's article noted above. ${ }^{117}$ The Grand Chamber expressly acknowledged its subsidiary role and held that regarding issues of "general policy" the Court should recognise the primary role of the domestic authorities, especially where the policy had ultimately been determined by democratic processes. This restraint by the Court when faced with a challenge, based upon qualified Convention rights, to a national law that had received overwhelming parliamentary support certainly accorded with the Brighton Declaration's encouragement for the Court to give greater prominence to both the principle of subsidiarity and margin of appreciation doctrine.

Interestingly, whilst participating in the work of the Grand Chamber Judge Wojtyczek, from Poland, has delivered separate opinions which articulate a view of subsidiarity within the domestic constitutional framework that has echoes of several of the conceptual views of subsidiarity outlined in the first part of our study. In the Case of Sindicatul Cel Bun v Romania ${ }^{118}$, the applicant trade union ("The Good Shepherd") had been formed by a number of Orthodox priests and lay employees of the Romanian Orthodox Church. The trade union applied to the Court of First Instance for registration as a trade union, but the local Archdiocese objected on the ground that the creation of a trade union by members of the Church required the consent of the Archbishop (which he had not given) in accordance with the Statute of the Church (which was approved by a Government Ordinance). Eventually, the Romanian courts refused to register the applicant. The trade union then lodged a complaint at Strasbourg alleging a breach its members' right to form a trade union laid down in Article 11 of the ECHR. The Grand Chamber, by eleven votes to six, reversed the judgment of the Chamber (given by five votes to two) and found no breach of Article 11. The majority in the Grand Chamber determined, on the basis of a lack of a consensus amongst Contracting States, that States had a wide margin of appreciation to decide whether to recognise trade unions operating within religious communities. Whilst the Grand Chamber majority did not

\footnotetext{
114 Ibid. at para. 153.

115 Ibid. at para. 154.

${ }^{116}$ Partly Dissenting Opinion of Judges Nussberger and Jaderblom at para. 5.

${ }^{117}$ Supra n. 35.

118 Judgment of 9 July 2013.
} 
discuss the principle of subsidiarity, the judgment focused on the Convention obligation of States to defer to the autonomy of their religious organisations.

In this connection, the Court observes that it has frequently emphasised the State's role as the neutral and impartial organiser of the practice of religions, faiths and beliefs, and has stated that this role is conducive to public order, religious harmony and tolerance in a democratic society, particularly between opposing groups... It can only confirm this position in the present case. Respect for the autonomy of religious communities recognised by the State implies, in particular, that the State should accept the right of such communities to react, in accordance with their own rules and interests, to any dissident movements emerging within them that might pose a threat to their cohesion, image or unity. It is therefore not the task of the national authorities to act as the arbiter between religious communities and the various dissident factions that exist or may emerge within them. ${ }^{119}$

Judge Wojtyczek issued a concurring opinion in which he expressed his doubts about whether the right to form trade unions, contained in Article 11, was applicable to persons holding clerical office. As part of his analysis he identified the important principle governing the interpretation of the Convention that:

...according to the Preamble to the Convention, fundamental freedoms are best maintained by an "effective political democracy". In addition, any restrictions on the various freedoms safeguarded by the Convention must be "necessary in a democratic society". The interpretation of the Convention must therefore have due regard for the democratic ideal. Among the different characteristics of a democratic State, the principle of State subsidiarity should not be overlooked. A democratic society will flourish in a subsidiary State which observes the autonomy of the various communities of which it is made up. Such legitimate autonomy may be reflected, for example, in self-regulation by means of extra-legal rules of conduct produced or accepted by different social groups. ${ }^{120}$

So Judge Wojtyczek was identifying a concept of subsidiarity within the domestic relations between governmental bodies and other groupings in a particular society, that sought to place limitations on the acceptability of the former intervening in the internal affairs of the latter. He traced the Convention foundations of that requirement to the Preamble and limitation clauses embodied in Articles 8 to 11 of the ECHR. ${ }^{121}$ These provisions are not commonly cited as the sources of the Court's principle of subsidiarity, but Judge Wojtyczek was invoking a different intra State notion of subsidiarity which he then applied to interpret the Convention. His analysis also provides a more theoretical justification for the majority's invocation of the idea of autonomy in church and state relations.

\footnotetext{
${ }^{119}$ Ibid. at para. 165.

${ }^{120}$ Concurring Opinion of Judge Wojtyczek at para. 2.

${ }^{121}$ For a study of the Court's wider jurisprudence on democracy see, A. Mowbray, “Contemporary Aspects of the Promotion of Democracy by the European Court of Human Rights" 20(3) Eur. Pub. L. 469 (2014).
} 
Subsequently in O'Keeffee $v$ Ireland ${ }^{122}$, Judge Wojtyczek joined four other judges in issuing a partly dissenting opinion which, almost verbatim, repeated his conception of intra State subsidiarity delivered in Sindicatul. Ms O'Keeffee, when nine years old, had suffered terrible sexual abuse by her head-teacher whilst attending a Roman Catholic owned and run school. She tried to suppress the consequences of that abuse, but over two decades later (after she had been contacted by the police and received counselling) she brought civil proceedings against her abuser and state authorities seeking compensation. Her abuser did not defend her claim, but the government successfully argued that it was not liable for her abuse. She then lodged a complaint at Strasbourg contending, inter alia, that the respondent State had failed to comply with its Convention positive obligation to protect her from Article 3 abuse by the teacher. The case was relinquished to the Grand Chamber. A large majority of the Grand Chamber (eleven votes to six) went on to conclude that Ireland had failed to comply with its positive obligation of protection regarding the applicant's abuse in 1973. Judge Wojtyczek and his colleagues sympathised with the applicant for her suffering and agreed with the majority that States were under a Convention duty to take appropriate measures to protect children. However, they regretted that they were:

...unable to follow the majority in their analysis and conclusions as to the scope of the positive obligations of the State in the circumstances of the present case. These positive obligations have to be construed with due consideration to the different values and rights protected by the Convention. According to the Preamble to the Convention, fundamental freedoms are best maintained in an effective political democracy. The notion of a democratic society encompasses the idea of subsidiarity. A democratic society may flourish only in a State that respects the principle of subsidiarity and allows the different social actors to self-regulate their activities. This applies also to the domain of education. Legislation pertaining to private education should respect the legitimate autonomy of private schools. Article 2 of Protocol No. 1 guarantees the right of parents to ensure education and teaching in conformity with their own religious and philosophical convictions. It is clear that the democratic State has to respect the education choices of the parents as well as the parents' primary responsibility for the development and well-being of their children. ${ }^{123}$

The dissenters further criticised the majority for retrospectively applying contemporary positive obligation standards to events that occurred four decades ago. ${ }^{124}$

In O'Keeffe we can see Judge Wojtyczek's concept of subsidiarity being applied by the dissenters in the different jurisprudential area of Convention positive obligations. Nevertheless, there are similarities in the institutional context between Sindicatul and O'Keeffe as both involved the relationships between state bodies and (powerful) religious organisations. According to his view of subsidiarity state agencies should exercise restraint in their regulation of the latter whether they be controlling the activities of their

\footnotetext{
122 Judgment of 28 January 2014.

${ }^{123}$ Joint Partly Dissenting Opinion of Judges Zupancic, Gyulumyan, Kalaydjieva, De Gaetano and Wojtyczek at para. 7.

${ }^{124}$ For my concerns about the reasoning of the majority see supra n.3 at p.597.
} 
religious office-holders or be providing schooling. In neither case did Judge Wojtyczek specify the intellectual origins of his belief that an element of a democratic society is state organs respecting the subsidiarity of component communities. However, we have discovered that both religious ${ }^{125}$ and secular ${ }^{126}$ proponents of subsidiarity have advocated views that are compatible with his idea of intra State restraint by governmental authorities.

(iv) Quantitative references to the principle of subsidiarity in reports of Court judgments

Our focus has been on the Court's evolving jurisprudential usage of the principle and that has involved examining the qualitative features of the principle. We can now, briefly, consider how frequently subsidiarity has been mentioned in reports of judgments of the Court. An "advanced search" of the Court's HUDOC database, on 25 June 2014, for the term "subsidiarity" in the text of Court judgments generated 240 hits. ${ }^{127}$ These comprised 70 Grand Chamber judgments (including two duplicate non-English/French language translations) and 170 Chamber judgments (including one duplicate nonEnglish/French language translation). Looking first at the Grand Chamber's statistics they can be subdivided into the following three eras reflecting our earlier qualitative analysis:

\begin{tabular}{|l|l|l|l|}
\hline Era & $\begin{array}{l}\text { Total number of } \\
\text { cases containing a } \\
\text { reference } \\
\text { "subsidiarity" }\end{array}$ & $\begin{array}{l}\text { Time period } \\
\text { references per year }\end{array}$ \\
\hline $\begin{array}{l}\text { Post-Interlaken: } \\
2010 \text { to June 2014 }\end{array}$ & 29 & 4.5 years & 6.4 \\
\hline $\begin{array}{l}\text { Full-time Court: } \\
1999 \text { to 2009 }\end{array}$ & 35 & 11 years & 3.2 \\
\hline $\begin{array}{l}\text { Original Court: } \\
1996 \text { to } 1998\end{array}$ & 4 & 3 years & 1.3 \\
\hline
\end{tabular}

In regard to reports of Chamber judgments the statistics were:

\begin{tabular}{|l|l|l|l|}
\hline Era & $\begin{array}{l}\text { Total number of } \\
\text { cases containing a } \\
\text { reference } \\
\text { "subsidiarity" }\end{array}$ & $\begin{array}{l}\text { Timerage number of } \\
\text { references per year }\end{array}$ \\
\hline $\begin{array}{l}\text { Post-Interlaken: } \\
2010 \text { to June 2014 }\end{array}$ & 89 & 4.5 years & 19.8 \\
\hline $\begin{array}{l}\text { Full-time Court: } \\
1999-2009\end{array}$ & 77 & 11 years & 7 \\
\hline $\begin{array}{l}\text { Original Court: } \\
1992 \text { to } 1998\end{array}$ & 3 & 7 years & 0.43 \\
\hline
\end{tabular}

\footnotetext{
${ }^{125}$ Such as Pope Pius XI supra n. 8.

${ }^{126}$ Like the liberal contractualists supra n. 15.

${ }^{127}$ Due to the vagaries of the HUDOC system a "Search in Document Sections" of "Complaints", "The Law" and "For These Reasons" generated no returns.
} 
\begin{tabular}{|l|l|l|} 
& & \\
\hline
\end{tabular}

Of course, it must be appreciated that the role of the Court fundamentally altered after Protocol No. 11 of the ECHR ${ }^{128}$ came into effect in November 1998 and subsequently the annual total of judgments delivered rose from 177 in 1999 to a peak of 1,625 in $2009^{129}$ and then declined to 916 in 2013. ${ }^{130}$ However, the figures for the post-Interlaken era show reports of judgments from both the Grand Chamber and Chambers containing noticeably higher yearly average numbers of references to subsidiarity. If we drill down into the reports of Grand Chamber judgments since Interlaken we can see the actors making those references to subsidiarity and the frequency of their references (noting that in some cases more than one actor referred to the principle):

\begin{tabular}{|l|l|l|l|l|l|l|}
\hline Year & Applicant(s) & $\begin{array}{l}\text { Respondent } \\
\text { State }\end{array}$ & $\begin{array}{l}\text { Third-party } \\
\text { intervener(s) }\end{array}$ & $\begin{array}{l}\text { Judgment } \\
\text { of the } \\
\text { Court }\end{array}$ & $\begin{array}{l}\text { Concurring } \\
\text { Opinion }\end{array}$ & $\begin{array}{l}\text { Dissenting } \\
\text { Opinion }\end{array}$ \\
\hline 2014 & 1 & & & 2 & & 1 \\
\hline 2013 & & & 1 & 1 & 2 & 3 \\
\hline 2012 & 1 & 1 & & 3 & 1 & 3 \\
\hline 2011 & & & 1 & 2 & & 2 \\
\hline 2010 & & 3 & & 2 & 3 & 1 \\
\hline
\end{tabular}

From these figures we can discern that there has not been any noticeable increase in the numbers of respondent States raising the principle of subsidiarity before the Grand Chamber since 2010. This is perhaps surprising given the strong endorsement of the principle at the Interlaken Conference. Interestingly, the statistics do reveal that dissenting judgments make as many references to the principle as are found in judgments of the Court. This may be explained by the simple fact that dissenting judges can invoke the principle as a ground for criticising the majority in a variety of situations. For example, in Vinter and Others $v U K^{131}$, after condemning the abstract application of Article 3 of the ECHR by the majority Judge Villiger expressed the belief that such an approach did not "square easily with the principle of subsidiarity underlying the Convention". ${ }^{132}$ Also where dissenters consider that controversial policy decisions, like the regulation of hunting, should have been left to national parliaments ${ }^{133}$ or the majority have failed to accord sufficient respect to the decisions of national courts ${ }^{134}$

\footnotetext{
${ }^{128}$ Supra n.55.

${ }^{129}$ Annual Report 2010 at p. 137.

${ }^{130}$ Annual Report 2013 at p. 199.

131 Judgment of 9 July 2013.

132 Partly Dissenting Opinion of Judge Villiger at p. 64.

133 Joint Dissenting Opinion of Judges David Thor Bjorgvinsson, Vucinic and Nussberger in Herrmann $v$ Germany, Judgment of 26 June 2012 at p. 54.
}

\footnotetext{
${ }^{134}$ See Dissenting Opinion of Judge Steiner in Centro Europa 7 S.R.L. and Di Stefano v Italy, Judgment of 7 June 2012 at p. 67.
} 
they have cited the principle of subsidiarity to underpin their disagreements with majority judgments. In the deeply divided Grand Chamber case of Animal Defenders International $v \cup K^{135}$, five of the dissenters "[i]n the spirit of subsidiarity"136 were willing to consider the extensive legislative attention given to the Convention implications of the Bill continuing the UK's long-established general ban on television and radio advertisements of a political nature. But the dissenters believed that the majority (comprising a bare majority of nine judges) had accorded "excessive importance" ${ }^{137}$ to the domestic law-making process when finding that the ban did not infringe Article 10 of the ECHR. The dissenters' view also represents a challenge to Judge Spano's thesis about the Court's refinement of the principle of subsidiarity over recent years examined earlier in our study. ${ }^{138}$ As he acknowledged, when commenting upon Animal Defenders International, "not all of the judges of my Court have the same views on these issues, but that is inevitable, we are after all dealing with the core nature of the institutional status of the Court and its future development." ${ }^{139}$ Hence the breadth of usage by the Court of the principle in the case-law examined above is echoed in resort to the principle by dissentients.

\section{Conclusions}

From our examination of the Court's jurisprudence we have been able to identify the range of ECHR Articles that have been invoked as the textual foundations of the principle of subsidiarity within the Convention system. These are primarily Articles 1, 13, 19 and 35(1). ${ }^{140}$ We have also discovered that there has been a considerable degree of consistency in the uses of the principle throughout the three eras in the history of the Court identified in our study. Hence the Court has repeatedly taken a firm view on the need for applicants to exhaust domestic remedies before initiating proceedings at Strasbourg. ${ }^{141}$ Furthermore, the Court has regularly applied the margin of appreciation doctrine, which as we have learnt has been explained as being directly derived from the principle of subsidiarity. ${ }^{142}$ Indeed, Judge Spano has placed the margin of appreciation at the heart of his understanding of the contemporary "age of subsidiarity". ${ }^{143}$ However, we have also been able to discern new uses of the principle of subsidiarity by the Court as it

\footnotetext{
135 Judgment of 22 April 2013. I have previously analysed this case supra n.121 at pp. 482-484.

${ }^{136}$ Ibid. Joint Dissenting Opinion of Judges Ziemele, Sajo, Kalaydjiyeva, Vucinic and De Gaetano at para. 9.

137 Ibid.

${ }^{138}$ Supra n. 35.

${ }^{139}$ Supra n.4 at p.497.

${ }^{140}$ Supra pp. ${ }^{* * * * *}$

${ }^{141}$ Supra n.56.

${ }^{142}$ Supra n. 53.

${ }^{143}$ Supra n. 4.
} 
has adapted to its amended responsibilities and changing caseload. For example, the principle was applied to underpin the Court's altered stance on the application of Article 13 to complaints about excessive delays in domestic judicial proceedings. ${ }^{144}$

Our study also enables us to perceive the complexities of the principle of subsidiarity as the jurisprudence clearly demonstrates that it has not been applied simply as a device to restrict the powers of the Court. As we have seen the Grand Chamber has invoked the principle where domestic authorities have failed to engage in effective fact-finding regarding complaints alleging breaches of Convention rights and freedoms. ${ }^{145}$ The Grand Chamber has additionally used the principle in support of its ruling that domestic courts must adopt a strict approach to assessing whether those rights and freedoms have been violated. ${ }^{146}$ These judgments disclose that the principle of subsidiarity under the ECHR places legal obligations on domestic authorities. This may surprise, and perhaps dismay, States who have been vigorously promoting the principle at the recent inter-governmental conferences on the ECHR with the belief that it would limit the authority and activities of the Court. Indeed, it is significant that both of these Grand Chamber judgments were delivered during the post-Interlaken era and thereby demonstrate that during the "age of subsidiarity" the Court has not been afraid to apply the principle in ways that place specific duties on domestic authorities. Such judgments make plain the actual responsibilities of Contracting States as the primary guarantors of Convention rights and freedoms which is the other dimension of the principle of subsidiarity.

Another aspect of the complexity of the principle of subsidiarity within the ECHR system is that, as we have ascertained, it is not only States who can benefit from its application. Certainly, in circumstances where the Court recognises that a respondent State has a wide margin of appreciation that requires a corresponding degree of deference by the Court to the domestic policy-making process, especially where extensive parliamentary debate about the contested measure has occurred, the respondent State thereby gains the direct benefit that it is much less likely to be found in breach of the Convention. ${ }^{147}$ States may also be helped by the Court identifying systemic failings in domestic administrative schemes or legislative programmes via the pilot judgment process, which has been linked to the principle of subsidiarity. ${ }^{148}$ Furthermore, the many victims of such systemic failures can also be advantaged by the utilisation of the pilot judgment process along with the Committee of Ministers when undertaking its supervision of the execution of judgments. ${ }^{149}$ We have also encountered different scenarios in which the application of the principle of subsidiarity helps the Court, including avoiding the need for the Court to provide definitive rulings on questions of

\footnotetext{
${ }^{144}$ Supra n. 64.

${ }^{145}$ Supra n. 104.

${ }^{146}$ Supra n. 106.

${ }^{147}$ Supra n. 113.

${ }^{148}$ Supra n. 73.

${ }^{149}$ Under Article 46 of the ECHR.
} 
national $\operatorname{law}^{150}$ or determine disputed question of fact ${ }^{151}$. Consequently, the use of the principle of subsidiarity within the ECHR system can offer benefits to all the various actors in the Strasbourg process. Of course, not all the actors will always benefit by the application of the principle in every case, for example where the Court recognises a respondent State as having a wide margin of appreciation the applicant will inevitably find it much more difficult to establish a violation of the Convention. Nevertheless, the utilisation of the principle is not always a zero-sum game between applicants and respondent States as, for example, our previous discussion of pilot judgments has highlighted.

Our examination of some of the quantitative features of the principle's occurrence within the text of reports of Court judgments provided us with further insights into the complications associated with the utilisation of subsidiarity in Strasbourg proceedings. There was a noticeable increase in the yearly average numbers of references to subsidiarity in reports from both Chambers and the Grand Chamber during the postInterlaken period compared to throughout the first decade of the full-time Court's work. This provided extra credence to the post-Interlaken period being described as the "age of subsidiarity". However, it was rather surprising to see how few references respondent States made to subsidiarity in their reported submissions to the Grand Chamber in the post-Interlaken years, given the attention we have noted they lavished on the principle in the Interlaken and Brighton Conferences/Declarations. We also discovered that in contemporary times Grand Chamber dissenters were as likely to make reference to, and use, subsidiarity as the majority.

When we compared the Court's jurisprudence on the principle of subsidiarity with the wider philosophical, and religious, views of the concept of subsidiarity we found that it was Judge Wojtyczek's notion of an intra-State idea of subsidiarity that had the greatest similarities. This may, in large part, be explained by the fact that most of the theorists were focussed on national constitutional/governmental structures and activities, not the allocation of powers within a regional human rights jurisdiction encompassing forty seven sovereign States. Therefore, as Follesdal predicted ${ }^{152}$, the principle of subsidiarity is not the ultimate solution to the question of how power should be distributed between the Court and Contracting States. Nevertheless, it is, as we have discerned, a long-standing and fundamental jurisprudential tool in the decision-making of the Court.

\footnotetext{
${ }^{150}$ Supra n. 50.

${ }^{151}$ Supra n. 45.

${ }^{152}$ Supra n.16.
} 
